$\begin{array}{r}\text { Volume and Issues Obtainable at Center for Sustainability Research and Consultancy } \\ \text { Sustainable Business and Society in Emerging Economies } \\ \text { ISSN:2708-2172 \&(E):2708-2504 } \\ \text { Volume 3: Issue 3, September 2021 } \\ \text { CSRᄃ } \\ \text { Journal homepage: www.publishing.globalcsrc.org/sbsee } \\ \hline\end{array}$

\title{
Impact of Perceived CSR on Brand Equity through Brand Admiration and Customer Advocacy Behavior: Moderating Role of Brand Attitude and Customer Loyalty
}

Mashari Mahmood, University of Engineering \& Technology Lahore, Pakistan

*Amna Niazi, University of Engineering \& Technology Lahore, Pakistan

Waheed Asghar, Director in Technical Education and Vocational Training Authority, Govt of Punjab, Lahore, Pakistan

Mujahid Hussain, FAST School of Management, National University of Computer \& Emerging Sciences, Lahore Campus, Lahore, Pakistan

*Corresponding author's email: amnakn@ gmail.com

\begin{tabular}{l}
\hline ARTICLEDETAILS \\
\hline History \\
Revised format: Aug 2021 \\
Available Online: Sep 2021 \\
\hline Keywords \\
Perceived Corporate social \\
responsibility (CSR), Brand \\
Equity, Customer Advocacy \\
Behavior, Brand Admiration, \\
Brand Attitude \\
\hline
\end{tabular}

JEL Classification M1, M12

\section{OPEN ACCESS}

\begin{abstract}
Purpose: This study intends to explore the positive impact of perceived Corporate Social Responsibility (CSR) on brand equity with respect to behaviors and emotions. The motive behind this study was to examine the sequential mediating role of emotion of brand admiration and customer advocacy behavior between perceived CSR and brand equity. Moderators of brand attitude and customer loyalty were also explored in this study.
\end{abstract}

Design/Methodology/Approach: Quantitative research method has been adapted for this study. A questionnaire with 5-point likert scale was adopted from existing scholarly work to collect data from 364 customers of 5 food production companies placed in Pakistan. Collected data were analyzed with the help of SPSS and Smart PLS3 through Structural Equation Modeling (SEM) technique.

Findings: Results show that brand admiration and customer advocacy behavior significantly mediate the relationship of perceived CSR and brand equity. Moreover, moderating role of brand attitude and customer loyalty was found positive and significant. This was the novelty of this research.

Implications/Originality/Value: This research will be helpful for food production companies in Pakistan to formulate strong customerbrand relationships in order to strengthen their brand equity by effectively positioning their CSR practices into the minds of consumers.

(C2021 The authors, under a Creative Commons Attribution- Non

Commercial- 4.0

Recommended citation: Mahmood, M., Niazi, A., Asghar, W. and Hussain, M. (2021). Impact of Perceived CSR on Brand Equity through Brand Admiration and Customer Advocacy Behavior; Moderating Role of Brand Attitude and Customer Loyalty. Sustainable Business and Society in Emerging Economies, 3 (3), 177-194. 


\section{Introduction}

Corporate Social Responsibility (CSR) has become mandatory in post-modern business environment as long term success of any company is associated with it. Companies are paying more attention towards well-being and protection of social surroundings by investing in corporate resources. Smith (2012) showed that 60 percent buying behaviors of people have been influenced by their understanding of company's CSR activities. It has been figured out that 77 percent of the customers around the globe choose those companies which are socially responsible and they do not hesitate to pay an extra 5-10 percent for these companies 'deal. 74 percent of those customers are labeled "Social Activators" because they can influence buying behaviors of other customers by putting warm words about those companies on social networks (Times, 2017). By adopting CSR strategy, businesses can be able to achieve their organizational goals and popularity in society that eventually contributed to their non-expendable growth (Luo \& Bhattacharya, 2006). It is really important to understand that CSR is about giving back to society, which is something totally separate from rights and obligations of promoters and owners of companies (Visser, 2007). CSR initiatives enhance firm reputation and it leads to high firm performance in terms of market share. Moreover, factor of risk has been minimized by engaging in CSR and it is also influenced by firm reputation (Liu \& Lu, 2019). Study revealed that business ethics are more closely related with customer's attitude towards brand but value of CSR cannot be ignored (Ferrell et al., 2019) Brand attitude shaped by positive CSR perception strengthens the desire of customer to purchase (Ramesh et al., 2019). By communicating CSR activities effectively, companies achieve supportive behaviors (word of mouth, citizenship behavior) from customers and build positive image at corporate level (Du et al., 2010).

Customer advocacy behavior is derived by some interrelated constructs in relationship marketing point of view. Research suggests that satisfaction, trust and commitment (three modules of commitment; affective, normative and continuance) are determinants of advocacy whereas commitment is key driver which effects customer's eagerness to endorse the company (Fullerton, 2011).Devoted customers show more enthusiasm to support firm as advocates and consumer commitment is positively influenced by diverse dimensions of perceived value (e.g. social, emotional and conditional) recommending that firms should convey exceptional customer values through their marketing strategies to effect customer's commitment (Mosavi \& Ghaedi, 2012). Customer advocacy generates positive word of mouth about company. Furthermore, it increases satisfaction level of customer towards company through providing better quality than competitors and as a result company finds more loyal and committed customers (Roy, 2013). Jiang et al., (2014) claimed that emotions are more crucial than any other element in ascertaining buying behaviors. Customer emotional attachment with brand driven by emotions generates sense of appreciation and consequently, customers actively connect with brand and promote it (Gómez-Suárez, 2019). Various emotional factors including brand love, personal attachment and self-concept engagement with brand dramatically boost brand loyalty (Hwang \& Kandampully, 2012).

Emotion of admiration is aroused by relating CSR to different organizational outputs such as product and service quality, global business creativity, corporate culture and ethical responsibilities (Cegarra-Navarro \& Martínez-Martínez, 2009). In order to offer strong brand value to customers, brand admiration needs to be build, enhanced and leveraged (Park et al., 2016) and brand admiration prompts increased purchase intentions of customers (Trivedi \& Sama, 2020).

Role of customer loyalty in making purchase decisions or support the brand has become matter of consideration. Loyalty of customer implies favorable and supporting behaviors and plays an integral role in financial development of companies (Tarigan \& Hatane, 2019).

Advocacy behavior of loyal customers drastically impact brand identity, which is a valuable asset to establish long-lasting presence in market (Shailesh \& Reddy, 2016). Recent studies have demonstrated that brand equity is amongst the leading indicators of customer-based brand performance framework that assesses brand excellence (Molinillo et al., 2019). 
Brand equity (consumer-based) leads to company's long-term success by delivering strategic advantage as it focuses on positioning the brand name in the minds of customers by providing higher value than alternatives (Fayrene \& Lee, 2011). Hence, Organizations should concentrate on consumer-based brand equity in order to acquire customer ownership behavior that helps in minimizing turnover intentions of customers(Raza et al., 2020).

In perspective of international fast-food chain based in Pakistan with diverse segmentation, scholars confirmed that good will of a brand defines its brand value and different domains of CSR significantly affect this occurrence (Mahmood \& Bashir, 2020). Recent studies have shed light on importance of CSR in the context of brand declaring it a vital precedent of brand creation and evaluation to get competitive edge in today's market (Venkatesh et al., 2020). So, this study is intended to extend previous CSR and customer-brand relationship literature by proposing new relations that improve brand equity.

CSR and customer advocacy is empirically tested in various studies by through emotions and individual moral characteristics/moral beliefs of customers. Further relationship between emotionally influenced advocacy behavior with brand equity in respect of CSR has not been explored by prior researches and suggested(González et al., 2019).Customer loyalty has been tested directly with customer advocacy and brand equity but its moderating role between both variables has not been explored and suggested (Shailesh\& Reddy, 2016). Brand attitude has been explored as antecedent of brand admiration but its moderating effect between perceived CSR and brand admiration has not been explored previously (Trivedi \& Sama, 2020).

It has been found that CSR activities create feeling of admiration in customers and they start to own the brand through their behavior (González et al., 2019) whereas brand equity has become backbone of any company for better performance and to sustain in the market. So, this study has examined how CSR activities generate brand equity through path analysis i.e. sequential mediation of brand admiration and brand advocacy. Customer-brand relationship has also become a matter to concentrate. Therefore, brand attitude of customers and customer loyalty was tested as moderators in this research. The present study assesses that how emotions, attitude and behaviors of customer affect on the relationship between perceived CSR and brand equity. Brand admiration is a new variable relatively and its mediating function along with customer advocacy behavior is critical in order to have strong brand equity. Moreover, moderating role of brand attitude and customer loyalty has been determined in this study. This study adds value to customer-brand literature to assist organizations to develop and evaluate their strategies regarding CSR with respect to customer's behavior to expand its brand equity which would contribute towards achievement organization's long term goals.

\section{Literature Review \& Hypotheses Development}

This study is based on the theoretical framework of Brown \& Dacin (1997), framework of Dick \& Basu (1994), theory of reasoned action and theoretical framework of Du et al., (2007). Direct relations between perceived CSR and brand admiration, between customer advocacy behavior brand equity, mediating role of brand admiration and customer advocacy behavior have got the support of theoretical model of Brown \& Dacin (1997) who established the model of CSR and customer responses to obtain brand value. Furthermore moderating role of customer loyalty has also been supported by theoretical model of Dick \& Basu (1994). Direct relation between brand admiration and customer advocacy behavior has been acknowledged by theoretical framework of Du et al., (2007). Whereas, moderating role of brand attitude has got the support of theory of reasoned action (Fishbein \& Ajzen, 1980).

\section{Perceived CSR and Brand Equity}

Corporate branding is an outcome of CSR practices by business organization while emphasizing on perspective of customers, showing that dedication for these practices is key to long-term success of 
organizations (Vassileva, 2009). Customer's response towards CSR practices of any organization holds massive importance as their perception effect organization's brand equity positively (Lai et al., 2010). Sheth \& Babiak, (2010) noted that social well-being has strong connection with customers and it results in improved brand image.Torres et al. (2012), after conducting study on worldwide brands, also gave the argument that CSR and global brand value of companies are in positive relationship. Moreover, credibility of any brand is relied upon its social obligations and responsibilities, resulting in brand equity (Hsu, 2012). It has been concluded that CSR has positive impact on customer-based brand equity via mediation of customer satisfaction (Ahmad et al., 2019). After reviewing relevant literature, following hypothesis is being proposed:

$\mathrm{H}_{1}$ : Perceived CSR has positive and significant impact on Brand Equity.

\section{Perceived CSR and Brand Admiration}

Emotions play critical role in shaping customer perception, feelings and behavior towards brand and these emotions are composed of multiple elements (Ivens et al., 2015). CSR is directly linked with emotions engendered by company because CSR inculcates emotions and thus customer's satisfaction and loyalty is reinforced (Pérez \& Del Bosque, 2015) and emotion of elevation accompanied by CSR perception of customer constructively stimulates behavioral reactions and hence increases the usage of environmentally friendly products(Romani et al., 2016). Feeling of gratitude is recognized as another emotion which is effected by CSR and produces favorable response from customers (Romani, Grappi, \& Bagozzi, 2013).Xie et al. (2019) argued that positive moral emotions such as gratitude, elevation and awe are induced in consumers by the means of their perception about Company's CSR activities.

This study centers on emotion of admiration. Emotions of admiration are produced when customers experience ongoing products or services of a brand with respect to 3Es of brand benefits i.e. enable, enrich and entice and finally induce better customer-brand relationship (Park et al., 2016). People perceive feeling of admiration when an individual or organization involves in any laudable action (Sweetman et al., 2013). Feelings of warmth and competence conceived by customers bring about admiration which every company or firm wants to earn from its customers (Aaker et al., 2012), whereas some past research noted that admiration is acquired from all stakeholders of company including customers when CSR activities are connected to diverse corporate objectives (Navarro \& Martínez, 2009). Recently, González et al. (2019) explored how perceived CSR is positively associated with feelings of admiration. After reviewing literature, following hypothesis is proposed:

$\mathrm{H}_{2}$ : There is a positive impact of perceived CSR on Brand Admiration.

\section{Brand Admiration and Customer Advocacy Behavior}

Customers with strong emotions for the brand show greater brand engagement as a response compared to those with low emotions (Leventhal, Franzak, Makarem, \& Jae, 2014) and emotional brand attachment ultimately leads to customer satisfaction (Dwivedi et al., 2019).Emotional satisfaction is a remarkable constituent of customer behavioral decisions including elevating product quality perception, high reviews, advocacy intentions and buying potential (Ladhari et al., 2017), whereas (Su \& Hsu, 2013) discussed that positive emotions is firm indicator of satisfaction and productive behaviors such as word of mouth and revisiting intentions. Advance researches added that variable of positive moral emotions alongside attitude leads to customer advocacy behavior towards CSR practices of socially responsible company (Xie et al., 2019).

Recently, few practitioners empirically illustrated the mediating role of customer emotions. For instance, Joireman et al., (2015) summarized that emotions held by customers mediate the association of CSR and behavioral reaction of customers and specifically, emotion of admiration is aroused through CSR actions perceived positively by customers and it brings forth favorable behaviors from them, i.e. consent to act as advocates of the company (González et al., 2019). 
$\mathrm{H}_{3}$ : There is a positive impact of Brand Admiration on Customer Advocacy Behavior.

\section{Customer Advocacy Behavior and Brand Equity}

Brand advocacy depends on customer engagement with brand, perceived review helpfulness and trust to enhance brand equity while discussing social media platforms (Mathur, 2019).Customer advocacy significantly raises brand equity in case of loyal customers and study suggests that importance of customer advocacy must be taken into account while implementing branding strategies (Shailesh \& Reddy, 2016).

Practitioners ended with the argument that along with other value addition behaviors, the brand advocacy of customers undoubtedly influences brand equity(Omar et al., 2020). Brand advocacy is positively related with brand equity and has impact on the relationship effects of CSR and its functions on brand equity (Pai et al., 2015). Hence, we propose following hypothesis after reviewing literature of these variables.

$\mathrm{H}_{4}$ : There is a positive relation between Customer Advocacy Behavior and Brand Equity.

\section{Brand Attitude as Moderator}

Moderating role of customer's attitude towards brand is acknowledged by previous researchers between relationship of CSR and customers responses. Attitude is an essential factor in examining the behavior, defined by theory of reasoned action (Fishbein \& Ajzen, 1980). Brand Attitude plays an insightful role in determining customer willingness to buy and it must be considered in customer-brand relationship (Trivedi, 2018). Positive Attitude towards brand results in admiration from customer and it indicates towards positive purchase intentions of customers (Trivedi \& Sama, 2020). Recent studies have indicated that there is strong relationship between CSR and customer's attitude towards brand (Ramesh et al., 2019). This study aims to determine the moderating role of Brand Attitude on the relation of perceived CSR and Brand Admiration.

$\mathrm{H}_{5}$ : Brand Attitude moderates the relation between perceived CSR and Brand Admiration.

\section{Customer Loyalty as Moderator}

The role of customer loyalty is crucial for companies in order to sustain their customers (Pritchard \& Howard, 1997). It is likely that more loyal customers a company has, the more probably they will endorse that company and by focusing this, a company can be transformed into a strong brand (Shailesh \& Reddy, 2016). Customer loyalty is established through their level of satisfaction and by concentrating on customer loyalty, advocacy behavior of customers can be improved (Tarigan \& Hatane, 2019). By reviewing past literature, we propose that customer loyalty moderates the association of emotion of admiration and brand advocacy.

$\mathrm{H}_{6}$ : Customer Loyalty moderates the relation between Customer Advocacy Behavior and Brand Equity.

\section{Mediating Role of Brand Admiration and Customer Advocacy Behavior}

Brown and Dacin, (1997) set up a theoretical framework for the first time to determine the relationship between CSR and customer's intentions and responses to generate brand value. With reference to that work, various studies had been attempted to evaluate CSR and consumer behavior and intentions (Vallejo et al., 2011; Pérez et al., 2013) and these outcomes strongly relate to brand equity (Mathur, 2019; Pai et al., 2015). Prior researchers found positive mediating function of brand admiration in context of CSR and consumer behavior (González et al., 2019). On the other hand, noteworthy role of customer advocacy behavior as mediator, has also been discussed by past scholars (Shailesh \& Reddy, 2016). Simultaneous mediating effect of brand admiration and customer advocacy behavior in CSRbrand domain has not been acknowledged by previous researchers. Hence, following hypothesis is being proposed: 
$\mathrm{H}_{7}$ : Brand Admiration and Customer Advocacy Behavior mediate the relation of perceived CSR with Brand Equity.

\section{Methodology}

Survey research method is carried out for this research. Deductive approach has been used to draw the results. Data was collected from respondents in quantitative form through survey. Survey method is defined as "a method of descriptive research used for collecting primary data based on verbal or written communication with a representative sample of individuals or respondents from the target population" (Mathiyazhagan \& Nandan, 2010). Questionnaire was adopted from the work of past researchers of same research area.Consumers familiar with the CSR activities of 5 Food Production Companies of Pakistan i.e. Nestle Foods, Gourmet Foods, Engro Foods, Sufi Foods and Unilever Foods are unit of analysis. Survey was conducted by distributing structured questionnaire through personal interaction and online survey forms (goggle forms) by using electronic mail and social media platforms. There are quite a lot of consumers of food industry in Pakistan. So, Target population is not known. According to(Krejcie \& Morgan, 1970), the sample size would be 384 while population is not specified. Therefore, 384 adult customers were selected as a sample size for data collection. It is easy to collect data from random consumers of food companies so, convenient sampling (non-probability) technique was applied.

\section{Measures}

Following table shows all research instrument with scale 1-5 (1= Strongly Disagree, 5= Strongly Agree) used to measure variables of this study along with their details.

Table 1: Research Instruments

\begin{tabular}{llc}
\hline \multicolumn{1}{c}{ Variable } & \multicolumn{1}{c}{ Reference (year) } & Items \\
\hline Perceived CSR & Alvarado-Herrera et al. (2017) & 18 \\
Brand Admiration & $\begin{array}{l}\text { Karjaluoto et al. (2016); Chaudhuri \& Holbrook (2001); Cho } \\
(2011)\end{array}$ & 14 \\
$\begin{array}{l}\text { Customer Advocacy } \\
\text { Behavior }\end{array}$ & Romani et al. (2013); Salzberger (2009) & 10 \\
$\begin{array}{l}\text { Brand Equity } \\
\text { Brand Attitude }\end{array}$ & Aaker (1991); Yoo et al. (2000); Yun (2006). & 12 \\
Customer Loyalty & Zeithaml et al. (1996) & 7
\end{tabular}

\section{Data Analysis}

Out of 384 questionnaires, 363 valid and complete responses were received back which reveals that response rate is approximately 92 percent (91.9\%). Structural Equation Modeling (SEM) technique has been used to analyze the collected data. Statistical tools were used for empiricalfindings from data. Data was analyzed via SPSS 22 and smart PLS 3. Firstly, data collected from respondents was entered in SPSS. After that, Smart PLS3 software was used to analyze that entered data. Results are drawn on the basis of data analysis.

\section{Demographical Information}

Age, gender and level of education are the demographic factors in this study. Male respondents are 62.3 percent while female respondents are 37.7 percent. Another demographic factor is educational level. Customers with $\mathrm{PhD}$ education were 14 percent, 50.4 percent responses obtained from consumers with qualification of Master (MS/M.Phil), 43.3 percent with Bachelors (B.A/BS/BBA) and 2.5 percent with Intermediate (FSC/F.A) background. There is no respondent with education of Metric or below. 


\begin{tabular}{|c|c|c|c|c|c|}
\hline Construct & Indicator & Loadings & $\begin{array}{c}\text { Cronbach's } \\
\text { Alpha (a) }\end{array}$ & $\begin{array}{l}\text { Composite } \\
\text { Reliability (CR) }\end{array}$ & $\begin{array}{l}\text { Average variance } \\
\text { Extracted (AVE) }\end{array}$ \\
\hline \multirow{18}{*}{$\begin{array}{l}\text { Perceived } \\
\text { CSR }\end{array}$} & PSCR1 & 0.610 & \multirow[t]{18}{*}{0.832} & \multirow[t]{18}{*}{0.840} & \multirow[t]{18}{*}{0.597} \\
\hline & PSCR2 & 0.678 & & & \\
\hline & PSCR3 & 0.640 & & & \\
\hline & PSCR4 & 0.616 & & & \\
\hline & PSCR5 & 0.562 & & & \\
\hline & PSCR6 & 0.702 & & & \\
\hline & PSCR7 & 0.724 & & & \\
\hline & PSCR8 & 0.698 & & & \\
\hline & PSCR9 & 0.680 & & & \\
\hline & PSCR10 & 0.710 & & & \\
\hline & PSCR11 & 0.621 & & & \\
\hline & PSCR12 & 0.620 & & & \\
\hline & PSCR13 & 0.084 & & & \\
\hline & PSCR14 & 0.059 & & & \\
\hline & PSCR15 & 0.073 & & & \\
\hline & PSCR16 & 0.065 & & & \\
\hline & PSCR17 & 0.074 & & & \\
\hline & PSCR18 & 0.092 & & & \\
\hline \multirow{14}{*}{$\begin{array}{l}\text { Brand } \\
\text { Admiration }\end{array}$} & BAD1 & 0.680 & \multirow[t]{14}{*}{0.917} & \multirow[t]{14}{*}{0.933} & \multirow[t]{14}{*}{0.520} \\
\hline & BAD2 & 0.689 & & & \\
\hline & BAD3 & 0.752 & & & \\
\hline & BAD4 & 0.703 & & & \\
\hline & BAD5 & 0.712 & & & \\
\hline & BAD6 & 0.798 & & & \\
\hline & BAD7 & 0.810 & & & \\
\hline & BAD8 & 0.832 & & & \\
\hline & BAD9 & 0.049 & & & \\
\hline & BAD10 & 0.737 & & & \\
\hline & BAD11 & 0.742 & & & \\
\hline & BAD12 & 0.720 & & & \\
\hline & BAD13 & 0.721 & & & \\
\hline & BAD14 & 0.808 & & & \\
\hline \multirow{7}{*}{$\begin{array}{l}\text { Brand } \\
\text { Attitude }\end{array}$} & BA1 & 0.719 & \multirow{7}{*}{0.898} & \multirow{7}{*}{0.920} & \multirow{7}{*}{0.622} \\
\hline & BA2 & 0.786 & & & \\
\hline & BA3 & 0.814 & & & \\
\hline & BA4 & 0.826 & & & \\
\hline & BA5 & 0.798 & & & \\
\hline & BA6 & 0.756 & & & \\
\hline & BA7 & 0.815 & & & \\
\hline
\end{tabular}




\begin{tabular}{|c|c|c|c|c|c|}
\hline \multirow[t]{11}{*}{$\begin{array}{l}\text { Brand Equity } \\
\text { Sustainable }\end{array}$} & $\begin{array}{l}\text { BE1 } \\
\text { pusiness and Society } \\
\text { BE2 }\end{array}$ & \begin{tabular}{|l}
0.566 \\
Emerging Ect \\
0.734
\end{tabular} & \multirow[t]{11}{*}{ nomies 0.908} & \multirow[t]{11}{*}{0.930} & \multirow[t]{11}{*}{ Vol. 3, No 3, September 2021} \\
\hline & BE3 & 0.689 & & & \\
\hline & BE4 & 0.753 & & & \\
\hline & BE5 & \begin{tabular}{|l|}
0.737 \\
\end{tabular} & & & \\
\hline & BE6 & \begin{tabular}{|l|}
0.748 \\
\end{tabular} & & & \\
\hline & BE7 & 0.734 & & & \\
\hline & BE8 & 0.712 & & & \\
\hline & BE9 & 0.773 & & & \\
\hline & BE10 & 0.644 & & & \\
\hline & BE11 & 0.672 & & & \\
\hline & BE12 & 0.696 & & & \\
\hline \multirow{10}{*}{$\begin{array}{l}\text { Customer } \\
\text { Advocacy } \\
\text { Behavior }\end{array}$} & CAB1 & 0.494 & \multirow[t]{10}{*}{0.882} & \multirow[t]{10}{*}{0.906} & \multirow[t]{10}{*}{0.664} \\
\hline & CAB2 & 0.436 & & & \\
\hline & CAB3 & 0.765 & & & \\
\hline & CAB4 & 0.779 & & & \\
\hline & CAB5 & 0.711 & & & \\
\hline & CAB6 & 0.743 & & & \\
\hline & CAB7 & 0.791 & & & \\
\hline & CAB8 & 0.762 & & & \\
\hline & CAB9 & 0.754 & & & \\
\hline & CAB10 & 0.715 & & & \\
\hline \multirow{8}{*}{$\begin{array}{l}\text { Customer } \\
\text { Loyalty }\end{array}$} & CL1 & 0.787 & \multirow[t]{8}{*}{0.890} & \multirow[t]{8}{*}{0.912} & \multirow[t]{8}{*}{0.565} \\
\hline & CL2 & 0.772 & & & \\
\hline & CL3 & 0.681 & & & \\
\hline & CL4 & \begin{tabular}{|l|}
0.779 \\
\end{tabular} & & & \\
\hline & CL5 & 0.766 & & & \\
\hline & CL6 & 0.774 & & & \\
\hline & CL7 & 0.711 & & & \\
\hline & CL8 & 0.737 & & & \\
\hline
\end{tabular}

In this study, respondents were given choice to select one food manufacturing company of their own choice out of 5. Out of 263 questionnaires, $49.9 \%$ were reported as customers of Nestle foods, $21.8 \%$ of Unilever foods, $16.3 \%$ of gourmet foods, $6.9 \%$ of Sufi foods and $5.2 \%$ of customers selected engro foods as their company (Appendix A). Demographics of the study are provided in Table 2.

Table 2: Demographics of the study

\begin{tabular}{ccc}
\hline Demographics & Categories & Responses \\
\hline Gender & Male & 226 \\
& Female & 137 \\
& $21-30$ & 299 \\
Age (Years) & $31-40$ & 51 \\
& $41-50$ & 9 \\
& $51-60$ & 4 \\
& Metric or Below & $\mathrm{N} / \mathrm{L}$ \\
Educational Level & Intermediate (FSC/FA) & 9 \\
& Bachelors (BS/BA/BBA) & 157 \\
& Masters (MS/M.Phil) & 183 \\
& PhD & 14 \\
\hline
\end{tabular}




\section{Results}

Quantitative findings are comprised of two steps of SEM-PLS analysis i.e. evaluation of measurement model (PLS Algorithm) and evaluation of path model (bootstrapping).

\section{Estimation of Measurement Model}

PLS algorithm is applied to test reliability, convergent validity and discriminant validity of constructs. Values including Cronbach's Alpha, Composite Reliability (CR) and Average Variance Extracted (AVE) are given below:

Table 3 shows the different values of each construct of the framework. Individual reliability of indicator is measured by loadings values (loadings ${ }^{2}$ ) and its value must be fall between 0.4-0.7 (Lin et al., 2016) which can be shown in Table 1 i.e. significant values. Both, Cronbach's alpha and composite reliability determine internal consistent reliability but composite reliability is more effective (Hair et al., 2016). Cronbach's Alpha value of each construct is more than 0.70 . Values of composite reliability are also higher than 0.70 as shown in the table which is positive indication for this research. Both values depict the prominent stage of internal consistent reliability. Value of AVE can also be seen in the table which is above than 0.5 in all columns and hence, it confirms the convergent validity (Hair et al., 2016).

Discriminant validity statistically shows the distinction of one construct from others. It includes FornellLarker Criterion developed by Fornell \& Larker (1981), study of cross-loadings and Heterotraitmonotrait ratio (HTMT). Cross loading values can be seen in Appendix B. Moreover, square root of AVE values are greater than their correlational values as described by Fornell-Larker criterion (Table 4). Lastly, values of HTMT in table 4 are less than 0.85 which indicates the appropriate discriminant validity (Zaiţ et al., 2011).

Table 4: Measurement Model (Discriminant Validity)

Fornell-Larker Criterion

\begin{tabular}{|c|c|c|c|c|c|c|c|c|c|c|c|c|}
\hline & BAD & BA & $\mathrm{BE}$ & CL & $\mathrm{CAB}$ & PCSR & BAD & $\mathrm{BA}$ & $\mathrm{BE}$ & CAB & CL & PCSR \\
\hline BAD & 0.791 & & & & & & & & & & & \\
\hline BA & 0.785 & 0.789 & & & & & 0.844 & & & & & \\
\hline $\mathrm{BE}$ & 0.679 & 0.692 & 0.787 & & & & 0.736 & 0.765 & & & & \\
\hline CL & 0.697 & 0.730 & 0.735 & 0.752 & & & 0.759 & 0.811 & 0.813 & & & \\
\hline $\mathrm{CAB}$ & 0.744 & 0.686 & 0.700 & 0.695 & 0.755 & & 0.819 & 0.776 & 0.776 & 0.841 & & \\
\hline PCSR & 0.539 & 0.491 & 0.437 & 0.450 & 0.492 & 0.548 & 0.542 & 0.496 & 0.450 & 0.511 & 0.468 & \\
\hline
\end{tabular}

Notes: $\mathrm{PCSR}=$ perceived $\mathrm{CSR}, \mathrm{BAD}=$ brand admiration, $\mathrm{BA}=$ brand attitude, $\mathrm{BE}=$ brand equity, $\mathrm{CL}=$ customer loyalty, $\mathrm{CAB}=$ customer advocacy behavior

\section{Evaluation of Path Model}

\section{Direct Effects}

Hypothesis testing is undertaken by structural model evaluation. The structural model (also known as inner model) consists of latent variables and their path relationships. $\mathrm{P}$ value, beta coefficient, $\mathrm{T}$-value, direct effects, total effects and specific indirect effect have been measured in path model. Path relationship between constructs was determined by path coefficients. In smart PLS, 500 subsamples bootstrapping method is applied through and it reveals values of path coefficients and loading of each construct with t-values. As per table 4, perceived CSR is positively effecting brand admiration $(\beta=0.202)$. Therefore, $\mathrm{H} 1$ is accepted. Moreover, brand admiration is directly related to customer advocacy behavior and its impact is positive $(\beta=0.375)$. In addition, direct impact of customer advocacy 
on brand equity is also positive and considerable $(\beta=0.70)$. These values show the acceptance of $\mathrm{H} 2$ and $\mathrm{H} 3$ respectively. Moderating impact of brand attitude on relationship of perceived CSR and brand admiration is tested positive and significant $(\beta=0.226)$ which is an indicator of acceptance of the hypothesis H4. Similarly, moderating effect of customer loyalty between association of brand admiration and customer advocacy behavior is also found positive and significant $(\beta=0$. 206). So, H5 is also acknowledged.

\section{Indirect Effects}

In Table 6, values show that indirect effect of perceived CSR and brand equity through sequential mediating role of brand admiration and customer advocacy behavior is noteworthy and positive $(\beta=0.053)$. Hence, H6 is also recognized. Here are the estimates of path model coefficients, T statistics, $P$ values and special indirect effects.

Table 5: Path Model Coefficients (Standard deviation, T Statistics, P Values)

\begin{tabular}{lccccc}
\hline & $\begin{array}{c}\text { Original } \\
\text { Sample (O) }\end{array}$ & $\begin{array}{c}\text { Sample } \\
\text { Mean } \\
(\mathbf{M})\end{array}$ & $\begin{array}{c}\text { Standard } \\
\text { Deviation } \\
(\text { STDEV) }\end{array}$ & $\begin{array}{c}\text { T Statistics } \\
(\mid \mathbf{O} / \text { STDEV|) }\end{array}$ & P Values \\
\hline BAD -> CAB & 0.375 & 0.371 & 0.055 & 6.869 & 0.000 \\
CAB -> BE & 0.700 & 0.704 & 0.031 & 22.722 & 0.000 \\
Moderating Effect 1 -> BAD & 0.226 & 0.227 & 0.031 & 3.815 & 0.004 \\
Moderating Effect 2 -> CAB & 0.206 & 0.208 & 0.020 & 2.157 & 0.002 \\
PCSR -> BAD & 0.202 & 0.209 & 0.050 & 4.019 & 0.000 \\
PCSR -> BE & 0.229 & 0.236 & 0.065 & 4.012 & 0.000 \\
BAD -> CAB & 0.375 & 0.371 & 0.055 & 6.869 & 0.000 \\
\hline
\end{tabular}

Table 6: Specific Indirect Effects (Standard deviation, T Statistics, P Values)

\begin{tabular}{lccccc}
\hline & $\begin{array}{c}\text { Original } \\
\text { Sample }(\mathbf{O})\end{array}$ & $\begin{array}{c}\text { Sample Mean } \\
(\mathbf{M})\end{array}$ & $\begin{array}{c}\text { Standard } \\
\text { Deviation } \\
\text { (STDEV) }\end{array}$ & $\begin{array}{c}\text { T Statistics } \\
(\mid \mathbf{O} / \text { STDEV|) }\end{array}$ & P Values \\
\hline BAD -> CAB -> BE & 0.238 & 0.237 & 0.039 & 6.062 & 0.000 \\
PCSR->BAD->CAB-> BE & 0.047 & 0.047 & 0.013 & 3.616 & 0.000 \\
\hline
\end{tabular}


Figure 1: Path Model Results

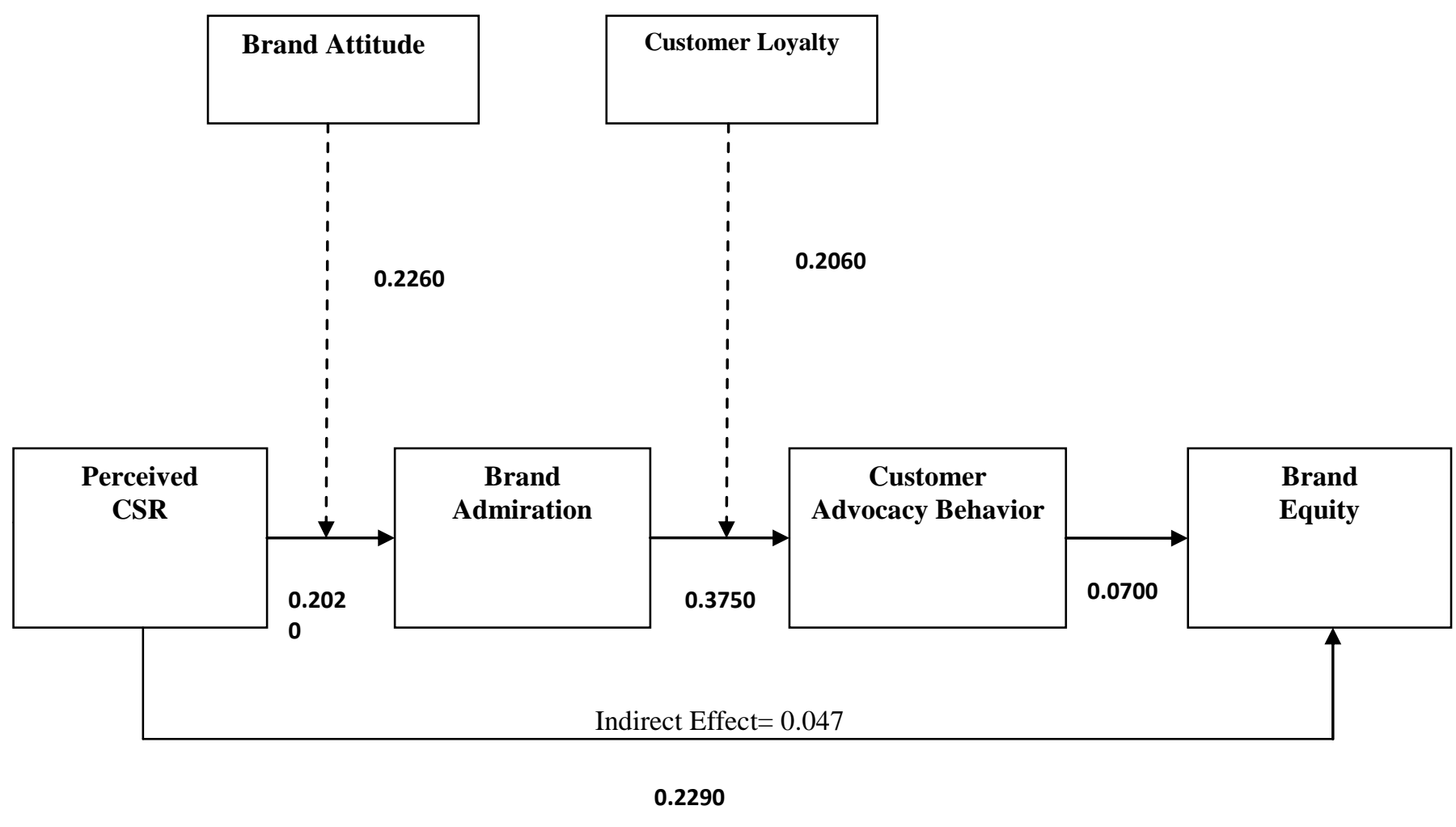

\section{Discussion and Recommendations}

Role of customer's emotions, attitudes and supportive behaviors had not been taken into account while strategizing CSR activities in food industry of Pakistan. Current study analyzed indirect impact of customer's perception of CSR on brand equity through emotions and behaviors of customers in reputed food production companies performing social responsibilities in Pakistan. There were two mediating factors i.e. brand admiration and customer advocacy behavior tested in the study. Additionally, two moderating variables i.e. brand attitude and customer loyalty were also tested. Subsequently, this study was conducted in context of food industry of Pakistan because prior literature was not sufficient on that specific context and region.

The empirical results of quantitative research revealed a positive relationship among perceived CSR and brand equity which is indication of acceptance of $\mathrm{H}_{1}$. Furthermore, results depict that customers' perception of social activities of organizations has a substantial impact on their emotions i.e. brand admiration which is hypothesis $2\left(\mathrm{H}_{2}\right)$. This outcome is aligned with the research work of previous researchers. Positive and significant bond between brand admiration and customer advocacy behavior has been explored through results of quantitative study. Hence, $\mathrm{H}_{3}$ is accepted.Association between customer advocacy behavior and brand equity is positive and significant through acceptance of $\mathrm{H}_{4}$. Moderating role of brand attitude between perceived CSR and brand admiration has been acknowledged positive. So, $\mathrm{H}_{5}$ is also recognized.Connection of brand admiration and customer advocacy behavior is positively moderated by customer loyalty as demonstrated through findings. Brand admiration results in more advocacy behavior from customer when moderated by customer loyalty. This was proposed through $\mathrm{H}_{6}$. Relationship of perceived CSR and brand equity through sequential mediation of brand admiration and customer advocacy behavior has been examined. Results show that both, brand admiration and customer advocacy behavior accompanied by CSR perception prominently influence brand equity and $\mathrm{H}_{7}$. 


\section{Theoretical and Practical Implications}

Present study is one of the rare ones in Pakistan being carried out in this particular area. In Pakistan, it shall participate tremendously in development of better society that companies especially, the food sector shall contribute more towards well-being of society through expending its CSR activities, consciously considering the consequences i.e. admiration from customers, favorable actions and strong brand base. Practical implications have been deduced:

This study offers that how companies can improve their brand equity from CSR activities through the factors brand admiration and customer advocacy behavior. In this regard, this study offers a detailed structure. Furthermore, brand attitude plays pivotal role in improvement of brand admiration and variable of customer loyalty helps to enhance customer advocacy behavior. Both of these outcomes are essential for building strong brand equity. In Pakistan, it shall participate tremendously in development of better society that companies especially, the food sector shall contribute more towards well-being of society through expending its CSR activities, consciously considering the consequences i.e. admiration from customers, favorable actions and strong brand base.

\section{Limitations and Future Direction}

Few limitations and future implications are identified as well. This study was conductionwith threedimensional CSR construct. In future studies, other domains of CSR may be explored. Additionally, this study was carried out in Pakistan's food production industry, which demonstrates that subsequent research can also be performed in context of other industries and service sector as well (e.g. banking, automobile and construction industry) and comparative analysis of different industries may also be conducted. Another limitation is methodological one. This study used convenience sampling technique, other methods could be used. Moreover, Data may be collected through any other type rather than crosssectional method (e.g. longitudinal) which was used in this research. Moderating variables like personal attributes of customers could be used in future. Brand admiration is relatively a new variable therefore; its dimensions i.e. brand trust, brand love and brand respect may be explored further with customer's behaviors by future researchers.

\section{Conclusion}

This study adds greater values to food production businesses that are looking for the better positioning of their brand through doing well for society. Generally, businesses conduct CSR practices for political or tax saving purposes and do not consciously look up towards customer's responses against those practices. This research provides comprehensive understanding about role of customer's perception of social responsibility initiatives taken by companies i.e. how they react and respond to those activities and how it affects brand equity of companies. SEM technique was used to analysis data collected from customers of food companies through convenient sampling method. Findings indicate that emotions and advocacy behaviors significantly impact CSR-brand relationship. Noteworthy positive effect of attitudes in shaping emotions and that of loyalty in determining their supportive behaviors have been shown as well.

\section{References}

Aaker, D. A. (1991). Managing Brand Equity New York: The free press.

Aaker, J. L., Garbinsky, E. N., \& Vohs, K. D. (2012). Cultivating admiration in brands: Warmth, competence, and landing in the "golden quadrant". Journal of Consumer Psychology, 22(2), 191194.

Ahmad, I., Shahzad, K., \& Gul, A. (2019). Mediating Role of Customer Satisfaction between Corporate Social Responsibility and Customer-Based Brand Equity. Business \& Economic Review, 11(1), 123-144. 
Brown, T. J., \& Dacin, P. A. (1997). The company and the product: Corporate associations and consumer product responses. Journal of marketing, 61(1), 68-84.

Castro-González, S., Bande, B., Fernández-Ferrín, P., \& Kimura, T. (2019). Corporate social responsibility and consumer advocacy behaviors: the importance of emotions and moral virtues. Journal of cleaner production, 231, 846-855.

Cegarra- Navarro, J. G., \& Martínez- Martínez, A. (2009). Linking corporate social responsibility with admiration through organizational outcomes. Social Responsibility Journal.

Cho, E. (2011). Development of a brand image scale and the impact of lovemarks on brand equity.

Du, S., Bhattacharya, C. B., \& Sen, S. (2007). Reaping relational rewards from corporate social responsibility: The role of competitive positioning. International journal of research in marketing, 24(3), 224-241.

Du, S., Bhattacharya, C. B., \& Sen, S. (2010). Maximizing business returns to corporate social responsibility (CSR): The role of CSR communication. International journal of management reviews, 12(1), 8-19.

Du, S., Bhattacharya, C. B., \& Sen, S. (2011). Corporate social responsibility and competitive advantage: Overcoming the trust barrier. Management Science, 57(9), 1528-1545.

Dick, A. S., \& Basu, K. (1994). Customer loyalty: toward an integrated conceptual framework. Journal of the academy of marketing science, 22(2), 99-113.

Dwivedi, A., Johnson, L. W., Wilkie, D. C., \& De Araujo-Gil, L. (2019). Consumer emotional brand attachment with social media brands and social media brand equity. European Journal of Marketing.

Ferrell, O. C., Harrison, D. E., Ferrell, L., \& Hair, J. F. (2019). Business ethics, corporate social responsibility, and brand attitudes: An exploratory study. Journal of Business Research, 95, 491501.

Fayrene, C. Y., \& Lee, G. C. (2011). Customer-based brand equity: A literature review. Researchers World, 2(1), 33.

Fishbein, M., \& Ajzen, I. (1980). Understanding attitudes and predicting social behavior.

Fullerton, G. (2011). Creating advocates: The roles of satisfaction, trust and commitment. Journal of Retailing and Consumer Services, 18(1), 92-100.

Gómez-Suárez, M. (2019). Examining Customer-Brand Relationships: A Critical Approach to Empirical Models on Brand Attachment, Love, and Engagement. Administrative Sciences, 9(1), 10.

Ha, H. Y., John, J., Janda, S., \& Muthaly, S. (2011). The effects of advertising spending on brand loyalty in services. European Journal of Marketing.

Hair Jr, J. F., Hult, G. T. M., Ringle, C., \& Sarstedt, M. (2016). A primer on partial least squares structural equation modeling (PLS-SEM): Sage publications.

Holbrook, M. B., \& Batra, R. (1987). Assessing the role of emotions as mediators of consumer responses to advertising. Journal of consumer research, 14(3), 404-420.

Homer, P. M. (1990). The mediating role of attitude toward the ad: Some additional evidence. Journal of Marketing research, 27(1), 78-86.

Hsu, K. T. (2012). The advertising effects of corporate social responsibility on corporate reputation and brand equity: Evidence from the life insurance industry in Taiwan. Journal of business ethics, 109(2), 189-201.

Hwang, J., \& Kandampully, J. (2012). The role of emotional aspects in younger consumer- brand relationships. Journal of Product \& Brand Management. 
Ivens, B. S., Leischnig, A., Muller, B., \& Valta, K. (2015). On the role of brand stereotypes in shaping consumer response toward brands: An empirical examination of direct and mediating effects of warmth and competence. Psychology \& Marketing, 32(8), 808-820.

Kotler, P., Armstrong, G., \& Warren, R. (1996). Principles of Marketing, Third Canadian Edition, Philip Kotler, Gary Armstrong, Margaret H. Cunningham, Robert Warren: Instructor's Manual: Prentice Hall Canada.

Krejcie, R. V., \& Morgan, D. W. (1970). Determining sample size for research activities. Educational and psychological measurement, 30(3), 607-610.

Ladhari, R., Souiden, N., \& Dufour, B. (2017). The role of emotions in utilitarian service settings: The effects of emotional satisfaction on product perception and behavioral intentions. Journal of Retailing and Consumer Services, 34, 10-18.

Lai, C.-S., Chiu, C.-J., Yang, C.-F., \& Pai, D.-C. (2010). The effects of corporate social responsibility on brand performance: The mediating effect of industrial brand equity and corporate reputation. Journal of Business Ethics, 95(3), 457-469.

Leventhal, R. C., Franzak, F., Makarem, S., \& Jae, H. (2014). Design benefits, emotional responses, and brand engagement. Journal of Product \& Brand Management.

Lin, H. F., Su, J. Q., \& Higgins, A. (2016). How dynamic capabilities affect adoption of management innovations. Journal of Business Research, 69(2), 862-876.

Liu, M., \& Lu, W. (2019). Corporate social responsibility, firm performance, and firm risk: the role of firm reputation. Asia-Pacific Journal of Accounting \& Economics, 1-21.

Luo, X., \& Bhattacharya, C. B. (2006). Corporate social responsibility, customer satisfaction, and market value. Journal of marketing, 70(4), 1-18.

Mahmood, A., \& Bashir, J. (2020). How does corporate social responsibility transform brand reputation into brand equity? Economic and noneconomic perspectives of CSR. International Journal of Engineering Business Management, 12, 1847979020927547.

Mathiyazhagan, T., \& Nandan, D. (2010). Survey research method. pp-34.

Mathur, M. (2019). Building brand advocacy on social media to improve brand equity. International Journal of Electronic Marketing and Retailing, 10(2), 150-172.

Matute- Vallejo, J., Bravo, R., \& Pina, J. M. (2011). The influence of corporate social responsibility and price fairness on customer behaviour: evidence from the financial sector. Corporate Social Responsibility and Environmental Management, 18(6), 317-331.

Molinillo, S., Ekinci, Y., \& Japutra, A. (2019). A consumer-based brand performance model for assessing brand success. International Journal of Market Research, 61(1), 93-110.

Mosavi, S. A., \& Ghaedi, M. (2012). A survey on the relationships between customer satisfaction, image, trust and customer advocacy behavior. African journal of business management, 6(8), 2897.

Mudambi, S. M., Doyle, P., \& Wong, V. (1997). An exploration of branding in industrial markets. Industrial marketing management, 26(5), 433-446.

Omar, N. A., Kassim, A. S., Shah, N. U., Shah Alam, S., \& Che Wel, C. A. (2020). The Influence of Customer Value Co-Creation Behavior on SME Brand Equity: An Empirical Analysis. Iranian Journal of Management Studies, 13(2), 165-196.

Pai, D.-C., Lai, C.-S., Chiu, C.-J., \& Yang, C.-F. (2015). Corporate social responsibility and brand advocacy in business-to-business market: The mediated moderating effect of attribution. Journal of Business Ethics, 126(4), 685-696.

Park, C. W., MacInnis, D. J., \& Eisingerich, A. B. (2016). Brand admiration: Building a business people love: John Wiley \& Sons. 
Pérez, A., \& Del Bosque, I. R. (2015). An integrative framework to understand how CSR affects customer loyalty through identification, emotions and satisfaction. Journal of Business Ethics, 129(3), 571-584.

Pérez, A., Salmones, M. d. M. G. d. 1., \& Bosque, I. R. d. (2013). The effect of corporate associations on consumer behaviour. European Journal of Marketing, 47(1-2), 218-238.

Pritchard, M. P., \& Howard, D. R. (1997). The loyal traveler: Examining a typology of service patronage. Journal of travel research, 35(4), 2-10.

Ramesh, K., Saha, R., Goswami, S., \& Dahiya, R. (2019). Consumer's response to CSR activities: Mediating role of brand image and brand attitude. Corporate Social Responsibility and Environmental Management, 26(2), 377-387.

Raza, M., Salleh, S., Tariq, B., Altayyar, R., \& Shaari, H. (2020). Investigating the effects of customerbased brand equity on turnover intentions with mediating effect of customer citizenship behavior. Management Science Letters, 10(2), 279-286.

Romani, S., Grappi, S., \& Bagozzi, R. P. (2013). Explaining consumer reactions to corporate social responsibility: The role of gratitude and altruistic values. Journal of Business Ethics, 114(2), 193-206.

Romani, S., Grappi, S., \& Bagozzi, R. P. (2016). Corporate socially responsible initiatives and their effects on consumption of green products. Journal of Business Ethics, 135(2), 253-264.

Roy, S. K. (2013). Consequences of customer advocacy. Journal of Strategic Marketing, 21(3), 260-276.

Shailesh, G., \& Reddy, D. B. (2016). Mediation Role of Customer Advocacy in Customer Loyalty and Brand Equity Relationship-An Empirical Study in Context to In-store Brands. Indian Journal of Science and Technology, 9, 45.

Sheth, H., \& Babiak, K. M. (2010). Beyond the game: Perceptions and practices of corporate social responsibility in the professional sport industry. Journal of Business Ethics, 91(3), 433-450.

Su, L., \& Hsu, M. K. (2013). Service fairness, consumption emotions, satisfaction, and behavioral intentions: The experience of Chinese heritage tourists. Journal of Travel \& Tourism Marketing, 30(8), 786-805.

Sweetman, J., Spears, R., Livingstone, A. G., \& Manstead, A. S. (2013). Admiration regulates social hierarchy: Antecedents, dispositions, and effects on intergroup behavior. Journal of experimental social psychology, 49(3), 534-542.

Tarigan, J., \& Hatane, S. E. (2019). The Influence of Customer Satisfaction on Financial Performance Through Customer Loyalty and Customer Advocacy: A Case Study of Indonesias Local Brand. Kne Publishing.

Times, T. E. (2017, Jauaray 25,2017). Consumers prefer socially responsible brands: Study, Economic Times. Retrieved from https://economictimes.indiatimes.com/news/company/corporatetrends/consumers-prefer-socially-responsible-brands-study/articleshow/56778815.cms

Torres, A., Bijmolt, T. H., Tribó, J. A., \& Verhoef, P. (2012). Generating global brand equity through corporate social responsibility to key stakeholders. International Journal of Research in Marketing, 29(1), 13-24.

Trivedi, J., \& Sama, R. (2020). The Effect of Influencer Marketing on Consumers' Brand Admiration and Online Purchase Intentions: An Emerging Market Perspective. Journal of Internet Commerce, 19(1), 103-124.

Trivedi, J. P. (2018). Measuring the comparative efficacy of an attractive celebrity influencer vis-à-vis an expert influencer-a fashion industry perspective. International Journal of Electronic Customer Relationship Management, 11(3), 256-271.

Vassileva, B. (2009). Corporate social responsibility-corporate branding relationship: an empirical comparative study. Management \& Marketing-Craiova(1), 13-28. 
Venkatesh, U., Mathew, J., \& Chaudhuri, A. (2020). Corporate Social Responsibility as an Antecedent of Brand Valuation Mandated Corporate Social Responsibility (pp. 175-198): Springer.

Visser, W. (2007). Developing countries. The A to Z of Corporate Social Responsibility, 154-157.

Wu, S.-I., \& Wang, W.-H. (2014). Impact of CSR perception on brand image, brand attitude and buying willingness: A study of a global café. International Journal of Marketing Studies, 6(6), 43.

Xie, C., Bagozzi, R. P., \& Grønhaug, K. (2019). The impact of corporate social responsibility on consumer brand advocacy: The role of moral emotions, attitudes, and individual differences. Journal of Business Research, 95, 514-530.

Zaiţ, A., \& Bertea, P. S. P. E. (2011). Methods for testing discriminant validity. Management \& Marketing Journal, 9(2), 217-224.

Zeithaml, V. A., Berry, L. L., \& Parasuraman, A. (1996). The behavioral consequences of service quality. Journal of marketing, 60(2), 31-46. 


\section{Appendix}

Table A: List of Variables, Definitions and Source

\begin{tabular}{|c|c|c|}
\hline Variable & Source & Definition \\
\hline Brand Equity & $\begin{array}{l}\text { Mudambi et al. } \\
\text { (1997) }\end{array}$ & "Total value added by the brand to the core product." \\
\hline Perceived CSR & Du et al. (2011) & $\begin{array}{c}\text { "Firm's commitment to maximize long-term economic, societal and } \\
\text { environmental well-being through business practices, policies and } \\
\text { resources." }\end{array}$ \\
\hline Brand Admiration & Park et al. (2016) & $\begin{array}{l}\text { "The degree to which customers have salient, personal connections with } \\
\text { the brand, emanating from trust in, love of, and respect for the brand." }\end{array}$ \\
\hline $\begin{array}{l}\text { Customer } \\
\text { Advocacy } \\
\text { Behavior }\end{array}$ & $\begin{array}{l}\text { Sen \& } \\
\text { Bhattacharya, } \\
\quad(2003)\end{array}$ & $\begin{array}{l}\text { "Brand Advocacy refers to consumer behavior which includes positive } \\
\text { word of mouth and resistance to unfavorable information about the } \\
\text { company." }\end{array}$ \\
\hline Customer Loyalty & Ha et al. (2011) & $\begin{array}{l}\text { "A deeply held commitment to re-buy or re-patronize a preferred } \\
\text { product/service consistently in the future, thereby causing repetitive } \\
\text { same-brand or same brand-set purchasing, despite situational influences } \\
\text { and marketing efforts having the potential to cause switching behavior." }\end{array}$ \\
\hline Brand Attitude & $\begin{array}{l}\text { Kotler et al. } \\
\quad(1996)\end{array}$ & $\begin{array}{c}\text { "Favorable or unfavorable evaluation of an individual for a specific brand } \\
\text { or product on the market." }\end{array}$ \\
\hline
\end{tabular}

Appendix A: Details of Respondent and Percentage

\begin{tabular}{|l|c|c|}
\hline \multicolumn{1}{|c|}{ Food Company } & No. of Customers & Percentage \\
\hline Nestle Foods & 181 & 49.9 \\
\hline Unilever Foods & 79 & 21.8 \\
\hline Gourmet Foods & 59 & 16.3 \\
\hline Sufi Foods & 25 & 6.9 \\
\hline Engro Foods & 19 & 5.2 \\
\hline
\end{tabular}

Appendix B: Cross Loading Values

\begin{tabular}{|l|r|r|r|r|r|r|}
\hline \multicolumn{1}{|c|}{ Indicators } & BAD & \multicolumn{1}{c|}{ BA } & \multicolumn{1}{l|}{ BE } & \multicolumn{1}{c|}{ CLAB } & PCSR \\
\hline BA1 & 0.555 & 0.719 & 0.446 & 0.485 & 0.439 & 0.332 \\
\hline BA2 & 0.591 & 0.786 & 0.511 & 0.572 & 0.549 & 0.404 \\
\hline BA3 & 0.614 & 0.814 & 0.544 & 0.592 & 0.532 & 0.437 \\
\hline BA4 & 0.619 & 0.826 & 0.566 & 0.585 & 0.562 & 0.366 \\
\hline BA5 & 0.594 & 0.798 & 0.547 & 0.59 & 0.524 & 0.389 \\
\hline BA6 & 0.637 & 0.756 & 0.562 & 0.579 & 0.547 & 0.384 \\
\hline BA7 & 0.707 & 0.815 & 0.62 & 0.615 & 0.612 & 0.393 \\
\hline BAD1 & 0.680 & 0.513 & 0.486 & 0.494 & 0.447 & 0.424 \\
\hline BAD10 & 0.737 & 0.514 & 0.49 & 0.533 & 0.598 & 0.41 \\
\hline BAD11 & 0.742 & 0.514 & 0.462 & 0.52 & 0.574 & 0.302 \\
\hline BAD12 & 0.720 & 0.620 & 0.50 & 0.502 & 0.506 & 0.375 \\
\hline BAD13 & 0.721 & 0.640 & 0.506 & 0.549 & 0.588 & 0.41 \\
\hline BAD14 & 0.808 & 0.605 & 0.54 & 0.563 & 0.636 & 0.368 \\
\hline
\end{tabular}




\begin{tabular}{|c|c|c|c|c|c|c|}
\hline BAD2 & 0.689 & 0.544 & 0.459 & 0.5 & 0.541 & 0.346 \\
\hline BAD3 & 0.752 & 0.587 & 0.523 & 0.493 & 0.558 & 0.449 \\
\hline BAD4 & 0.703 & 0.627 & 0.5 & 0.503 & 0.534 & 0.38 \\
\hline BAD5 & 0.712 & 0.565 & 0.481 & 0.465 & 0.486 & 0.435 \\
\hline BAD6 & 0.798 & 0.583 & 0.536 & 0.494 & 0.534 & 0.454 \\
\hline BAD7 & 0.810 & 0.648 & 0.518 & 0.554 & 0.576 & 0.45 \\
\hline BAD8 & 0.832 & 0.652 & 0.585 & 0.592 & 0.624 & 0.437 \\
\hline BAD9 & 0.049 & -0.012 & 0.016 & 0.001 & -0.043 & 0.021 \\
\hline BE1 & 0.366 & 0.472 & 0.566 & 0.442 & 0.349 & 0.243 \\
\hline BE10 & 0.456 & 0.454 & 0.644 & 0.533 & 0.47 & 0.222 \\
\hline BE11 & 0.449 & 0.43 & 0.672 & 0.534 & 0.518 & 0.278 \\
\hline BE12 & 0.468 & 0.476 & 0.696 & 0.538 & 0.505 & 0.283 \\
\hline BE2 & 0.536 & 0.6 & 0.734 & 0.641 & 0.524 & 0.384 \\
\hline BE3 & 0.473 & 0.511 & 0.689 & 0.525 & 0.477 & 0.362 \\
\hline BE4 & 0.46 & 0.489 & 0.753 & 0.532 & 0.483 & 0.317 \\
\hline BE5 & 0.533 & 0.55 & 0.737 & 0.50 & 0.525 & 0.36 \\
\hline BE6 & 0.463 & 0.418 & 0.748 & 0.476 & 0.493 & 0.362 \\
\hline BE7 & 0.535 & 0.477 & 0.734 & 0.481 & 0.571 & 0.362 \\
\hline BE8 & 0.507 & 0.501 & 0.712 & 0.472 & 0.47 & 0.235 \\
\hline BE9 & 0.479 & 0.493 & 0.773 & 0.551 & 0.506 & 0.271 \\
\hline CAB1 & 0.476 & 0.608 & 0.443 & 0.456 & 0.494 & 0.314 \\
\hline CAB10 & 0.545 & 0.528 & 0.534 & 0.599 & 0.715 & 0.329 \\
\hline CAB2 & 0.301 & 0.377 & 0.292 & 0.287 & 0.436 & 0.284 \\
\hline CAB3 & 0.543 & 0.476 & 0.502 & 0.609 & 0.765 & 0.444 \\
\hline CAB4 & 0.621 & 0.57 & 0.554 & 0.641 & 0.779 & 0.41 \\
\hline CAB5 & 0.546 & 0.411 & 0.475 & 0.518 & 0.711 & 0.354 \\
\hline CAB6 & 0.49 & 0.457 & 0.48 & 0.568 & 0.743 & 0.349 \\
\hline CAB7 & 0.591 & 0.509 & 0.573 & 0.648 & 0.791 & 0.389 \\
\hline CAB8 & 0.536 & 0.483 & 0.528 & 0.599 & 0.762 & 0.299 \\
\hline CAB9 & 0.516 & 0.413 & 0.486 & 0.572 & 0.754 & 0.285 \\
\hline CL1 & 0.592 & 0.592 & 0.654 & 0.787 & 0.715 & 0.37 \\
\hline CL2 & 0.560 & 0.578 & 0.603 & 0.772 & 0.605 & 0.377 \\
\hline CL3 & 0.476 & 0.455 & 0.48 & 0.681 & 0.531 & 0.293 \\
\hline CL4 & 0.546 & 0.585 & 0.584 & 0.779 & 0.632 & 0.37 \\
\hline CL5 & 0.535 & 0.602 & 0.529 & 0.766 & $\begin{array}{l}0.584 \\
\end{array}$ & 0.354 \\
\hline CL6 & 0.526 & 0.535 & 0.521 & 0.774 & 0.652 & 0.328 \\
\hline CL7 & 0.431 & 0.475 & 0.477 & 0.711 & 0.479 & 0.253 \\
\hline CL8 & 0.498 & 0.552 & 0.542 & 0.737 & 0.533 & 0.34 \\
\hline PCSR10 & 0.332 & 0.308 & 0.301 & 0.322 & 0.314 & 0.710 \\
\hline PCSR11 & 0.437 & 0.31 & 0.323 & 0.321 & 0.4 & 0.621 \\
\hline PCSR12 & 0.368 & 0.264 & 0.247 & 0.32 & 0.373 & 0.620 \\
\hline PCSR13 & -0.008 & 0.009 & -0.064 & -0.023 & -0.025 & 0.084 \\
\hline PCSR14 & -0.016 & -0.05 & -0.095 & -0.078 & -0.053 & 0.059 \\
\hline PCSR15 & 0.044 & 0.032 & 0.01 & 0.002 & -0.014 & 0.073 \\
\hline PCSR16 & 0.055 & 0.043 & -0.017 & 0.039 & 0.017 & 0.065 \\
\hline PCSR17 & 0.06 & 0.017 & -0.025 & -0.005 & 0.023 & 0.074 \\
\hline PCSR18 & 0.035 & 0.034 & -0.022 & 0.042 & -0.038 & 0.092 \\
\hline PCSR2 & 0.355 & 0.362 & 0.311 & 0.308 & 0.34 & 0.678 \\
\hline PCSR3 & 0.433 & 0.429 & 0.336 & 0.331 & 0.357 & 0.640 \\
\hline PCSR4 & 0.264 & 0.219 & 0.197 & 0.236 & 0.227 & 0.616 \\
\hline PCSR5 & 0.286 & 0.353 & 0.257 & 0.299 & 0.293 & 0.562 \\
\hline PCSR6 & 0.355 & 0.306 & 0.307 & 0.316 & 0.332 & 0.702 \\
\hline PCSR7 & 0.316 & 0.337 & 0.294 & 0.234 & 0.271 & 0.724 \\
\hline PCSR8 & 0.388 & 0.37 & 0.338 & 0.329 & 0.353 & 0.698 \\
\hline PCSR9 & 0.297 & 0.295 & 0.276 & 0.286 & 0.25 & 0.68 \\
\hline PCSR1 & 0.307 & 0.255 & 0.207 & 0.198 & 0.293 & 0.610 \\
\hline
\end{tabular}

